\title{
Pregnancy-specific protein $B$, progesterone concentrations and embryonic mortality during early pregnancy in dairy cows
}

\author{
P. Humblot, S. Camous*, J. Martal*, J. Charlery, N. Jeanguyot, M. Thibier \\ and R. G. Sasser†
}

\author{
Laboratoire d'hormonologie, U.N.C.E.I.A., B.P. 65, 94703-Maisons-Alfort, France; \\ *INRA, Domaine de Vilvert, 78350 Jouy-en-Josas, France; and \\ $\dagger$ Department of Animal Science, University of Idaho, Moscow, ID 83843, U.S.A.
}

\begin{abstract}
Summary. Pregnancy-specific protein B (PSPB) and progesterone concentrations were determined by RIAs in venous plasma during early pregnancy after 177 artificial inseminations (AI) performed in 76 cows and 71 heifers. The females were bled at 24 , $26,30-35$ days and $\sim 70$ days (for non-returns to oestrus) after AI. In non-pregnant females without extended CL maintenance (progesterone $<1.5 \mathrm{ng} / \mathrm{ml}$ on Day 24) and or showing a normal time of return to oestrus (Group 1, $N=63$ ), PSPB concentrations were undetectable whatever the stage after AI except in 2 cows. In pregnant animals $(\mathrm{N}=83$; Group 2) progesterone concentrations were $>10 \mathrm{ng} / \mathrm{ml}$ from Day 24 to the time of rectal palpation and PSPB concentrations rose continuously from $0.42 \pm 0.07$ (s.e.m.) $\mathrm{ng} / \mathrm{ml}$ (Day 24) to $4.06 \pm 0.3 \mathrm{ng} / \mathrm{ml}$ (time of rectal palpation). No coefficient of correlation between PSPB and progesterone concentrations was significant whatever the day of gestation studied. In cows with extended luteal function and subsequently found to be non-pregnant (late embryonic mortality) PSPB was undetectable ( $N=21$; Group 3) or detectable ( $N=10$; Group 4) at Days 24, 26 and/or 30-35 of pregnancy. At 24 and 26 days after AI progesterone concentrations were intermediate between those of Groups 1 and 2. At Day 24 females of Group 4 had higher progesterone concentrations than those of Group $3(P<0.05)$, but no differences between these two groups existed at subsequent stages after AI. Animals of Group 4 had lower PSBP concentrations than those of Group 2 between Days 24 and $30-35(P<0.025)$ but at the time of rectal palpation PSPB values fell to undetectable levels in all but 1 cow of Group 4. We conclude that (1) most pregnancy failures in cows are due to nonfertilization or early embryonic death and if $\mathrm{AI}$ is performed after 70 days post partum $>95 \%$ of these females have no detectable PSPB concentrations; (2) peripheral progesterone concentrations are lower at Days 24-26 after AI in cows with late embryonic mortality than in pregnant cows; (3) only $30 \%$ of non-pregnant females with extended luteal function (late embryonic mortality) have detectable PSPB levels which are lower than in pregnant cows; and (4) in pregnant animals there is no correlation between PSPB and progesterone concentrations. This suggests that under physiological conditions PSPB has no major effect on progesterone production or vice versa.
\end{abstract}

Keywords: PSPB; progesterone; pregnancy; embryonic death; cow

\section{Introduction}

The bovine conceptus produces numerous signals during early pregnancy. These include steroids, prostaglandins and proteins (Sauer, 1979; Shemesh et al., 1979; Gadsby et al., 1980; Lewis et al., 1982; Eley et al., 1983; Bartol et al., 1984; Knickerbocker et al., 1986). 
In-vivo studies (Northey \& French, 1980; Betteridge et al., 1980; Humblot \& Dalla Porta, 1984) have shown that the presence of a conceptus after Day 16 was necessary for maintenance of the corpus luteum (CL). Evidence that the signal originated from trophoblastic cells was supported by the effect of intrauterine deposition of trophoblastic extracts (Humblot \& Dalla Porta, 1984) or vesicles (Heyman et al., 1984). Helmer et al. (1985) and Knickerbocker et al. (1986) have further shown that the transient antiluteolytic action of the embryo was mediated by protein(s) similar to those previously found in sheep (Martal et al., 1979; Godkin et al., 1982, 1984a, b).

A pregnancy-specific protein (named bovine PSPB) isolated from cow placental membranes (Butler et al., 1982) is secreted by binucleate trophoblastic cells (Reimers et al., 1985). Development of a radioimmunoassay (RIA) has allowed determination of concentrations of PSPB in cow serum throughout pregnancy (Sasser et al., 1986) and, unlike antiluteolytic protein(s) (Martal et al., 1979; Godkin et al., 1982), PSPB seems to be secreted continuously throughout gestation with concentrations rising from the beginning to the end of pregnancy (Sasser et al., 1986). In the cow, pregnancy failure results mainly from embryonic mortality which may or may not result in prolongation of luteal function (Ayalon, 1978; Diskin \& Sreenan, 1980; Humblot, 1986). Plasma progesterone concentration at 22-24 days after insemination (Humblot, 1986) can help to distinguish early from late (after Day 16) cases of embryonic mortality, because the former induces no prolongation of progesterone secretion (Humblot \& Dalla Porta, 1984).

The objectives of this study were to determine (1) the change in PSPB concentrations in cow plasma during early pregnancy, (2) the plasma concentrations of PSPB with respect to late embryonic mortality as diagnosed by progesterone concentration and (3) the relationships between plasma concentration of PSPB and progesterone in early pregnancy.

\section{Materials and Methods}

Animals and treatments. The 76 cows (1-8 lactations) and 71 heifers (18-24 months old) were of the French Friesian breed and kept in free stable areas. The cows were inseminated at natural oestrus; only those inseminated after 70 days post partum were selected to avoid interference with PSPB present in the peripheral circulation during the post-partum period (Ruder \& Sasser, 1986). Heifers were systematically inseminated at 72 and $96 \mathrm{~h}$ after two i.m. injections of $25 \mathrm{mg}$ prostaglandin tromethamine salt (Dynolytic N.D.: Upjohn, Courbevoie, France) administered at 12-day intervals. Among these females, 17 cows and 9 heifers were used after two successive inseminations and 2 additional cows after three inseminations for a total of 177 sampling sequences after $\mathrm{AI}$.

Samples and assay procedures. The females were bled systematically at 24,26 and between 30 and 35 days after AI for determination of plasma progesterone and plasma PSPB concentrations. Rectal palpation was performed on cows or heifers not seen in oestrus at $70.5 \pm 9$ days after AI to confirm pregnancy $(N=120)$. An additional blood sample was taken at time of rectal palpation. Peripheral blood $(15 \mathrm{ml})$ was collected from the jugular vein into heparinized vacutainers (Beckton Dickinson, Grenoble, France). Plasma was separated by centrifugation (1000 $\mathrm{g}$ ) and stored at $-20^{\circ} \mathrm{C}$ until assayed.

An assay procedure previously described and validated by Thibier \& Saumande (1975) was used to determine progesterone concentration. Antiserum 111/6 (Specific Antisera Ltd, Wilmslow, Cheshire, U.K.) was raised in a goat against progesterone-1 $1 \alpha$-succinyl-BSA and was used at a final dilution of 1:12000. This antiserum displayed $<13 \%$ cross-reactivity with $17 \alpha$-hydroxyprogesterone. Progesterone and $17 \alpha$-hydroxyprogesterone were separated before RIA by Sephadex LH20 microcolumn chromatography. The accuracy and efficiency of this procedure were satisfactory as previously reported (Thibier et al., 1973). The sensitivity of the assay was $0.05 \mathrm{ng} / \mathrm{ml}$. Inter- and intra-assay coefficients of variation were $6.8 \%$ and $5.9 \%$ when duplicate estimates were run in the assays ( 7 assays) for a $1.5 \mathrm{ng} / \mathrm{ml}$ $(1.47 \pm 0.13)$ reference plasma sample, and $7 \%$ and $5.7 \%$ respectively when duplicate estimates were run (8 assays) for a $4 \mathrm{ng} / \mathrm{ml}(4 \cdot 27 \pm 0 \cdot 37)$ sample of reference plasma.

Validation criteria for the RIA for bovine PSPB have been described by Sasser et al. (1986). Assays were performed on $200 \mu$ l samples of plasma. Rabbit antiserum to bovine PSPB (RGS 38.1) was used at a final dilution of 1:300 000. It has been shown previously that there is minimal cross-reactivity $(<0.05 \%)$ in the assay with bovine LH and FSH and no reactivity with other hormones such as prolactin, TSH or GH. Mean sensitivity of the standard curve (standard preparation R-37) was 135 pg per assay tube. Intra- and inter-assay coefficients of variation were 6.8 and $20.4 \%$ respectively.

Data analysis. Females were declared non-pregnant when plasma progesterone concentrations were $<1.5 \mathrm{ng} / \mathrm{ml}$ at 24 days after AI. At all stages of pregnancy studied PSPB concentrations were considered significantly different from 
Table 1. Groups of animals and interpretation according to progesterone (Day 24) and PSPB concentrations, return to oestrus and rectal palpation

\begin{tabular}{|c|c|c|c|c|c|c|}
\hline Group & $\begin{array}{l}\text { Progesterone } \\
\text { conc. } \\
\text { (ng/ml) }\end{array}$ & PSPB & $\begin{array}{l}\text { Time of } \\
\text { oestrus } \\
\text { (days) }\end{array}$ & $\begin{array}{c}\text { Rectal } \\
\text { palpation }\end{array}$ & $\begin{array}{c}\text { No. }(\%) \\
\text { of } \\
\text { cows* }\end{array}$ & Interpretation \\
\hline $1+$ & $<1.5$ & Not detectable + & $\leqslant 24$ & - & $63(35 \cdot 6)$ & $\begin{array}{l}\text { Fertilization failure or } \\
\text { early embryonic mortality }\end{array}$ \\
\hline 2 & $>1 \cdot 5$ & Detectable§ & None & Pregnant & $83(46.9)$ & Gestation \\
\hline 3 & $>1.5$ & Not detectable & $>24 \uparrow$ & Not pregnant & $21(11 \cdot 9)$ & $\begin{array}{l}\text { Late embryonic mortality } \\
\text { (after Day 16) }\end{array}$ \\
\hline 4 & $>1 \cdot 5$ & Detectable & $>249$ & Not pregnant & $10(5 \cdot 7)$ & $\begin{array}{l}\text { Late embryonic mortality } \\
\text { (after Day 16) }\end{array}$ \\
\hline
\end{tabular}

*At the end of the trial.

†Includes 25 animals with progesterone $>1.5 \mathrm{ng} / \mathrm{ml}$, but observed in oestrus before 24 days.

fOnly 2 cows had detectable concentrations on Day 24 .

$\S$ On Day 24,26 or $30-35$.

ๆOr no return to oestrus.

zero when the two B/Bo replicates were $<95 \%$ of buffer control. Based upon the progesterone and PSPB concentrations, return to service, and results of rectal palpation, animals were assigned to one of four groups (Table 1). At each stage after AI, data were analysed by non-orthogonal analysis of variance (Snedecor \& Cochran, 1956). Multiple comparisons between groups were further studied by the method of Scheffé (Lellouch \& Lazar, 1974). Data are presented as mean \pm standard error of the mean (s.e.m.).

\section{Results}

\section{Progesterone and PSPB concentrations in non-pregnant animals (Group I)}

In non-pregnant animals without extended CL maintenance and/or showing return to oestrus at or before 24 days after AI $(\mathrm{N}=63)$, progesterone concentrations (Fig. 1) increased from $2 \pm 0.32 \mathrm{ng} / \mathrm{ml}$ on Day 24 to $6.2 \pm 0.5 \mathrm{ng} / \mathrm{ml}$ on Day $30-35$. This illustrates that a new oestrous cycle had begun before 24 days after AI. In these females, PSPB concentrations remained below the limit of detection of the assay, except in 2 cows. Those 2 cows had detectable PSPB values on Day $24(0.32$ and $0.31 \mathrm{ng} / \mathrm{ml})$ but these remained low $(<0.5 \mathrm{ng} / \mathrm{ml})$.

Progesterone and PSPB concentrations in pregnant animals (Group 2) and females exhibiting late embryonic mortality (Groups 3 and 4)

In pregnant animals (Group 2), from Day 24 to the time of rectal palpation, progesterone concentrations (Fig. 1) were above $10 \mathrm{ng} / \mathrm{ml}$. There was no change in progesterone concentration with age of gestation $(r=0.11 ;(P>0.05)$. Within each individual, progesterone concentrations at Days 24 and 26 were highly correlated with each other and, to a lesser extent, to concentration at Day 30-35 (Table 2). No relationship was found between progesterone concentrations at the beginning of pregnancy and at the time of rectal palpation.

Mean progesterone concentrations in females from Groups 3 and 4 (combined) were significantly lower $(P<0.001)$ at all stages studied when compared to those of pregnant cows. The multiple comparison analysis revealed that animals with non-detectable PSPB concentrations (Group 3) always had lower $(P<0.001)$ progesterone concentrations than did pregnant animals. In the 10 females with elevated PSPB concentrations (Group 4) the same observation was made at Days 26 and $30-35$ but progesterone concentrations at Day 24 were not significantly different from 

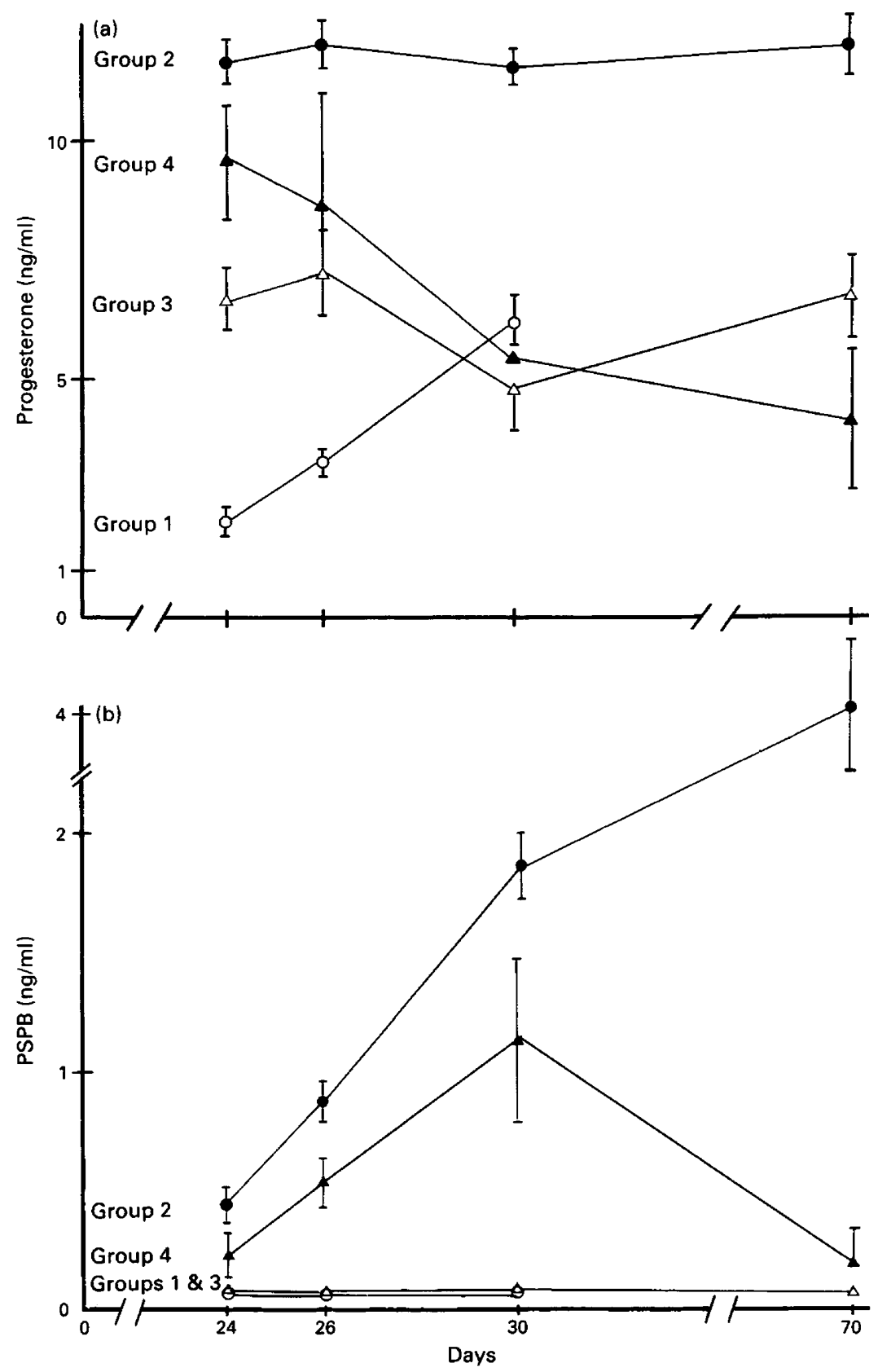

Fig. 1. Progesterone (a) and PSPB (b) concentrations after AI in cows in Groups 1-4 (see Table 1). Values are mean \pm s.e.m.

those of pregnant cows and heifers. At each stage studied the large variation in progesterone concentrations suggests that luteal regression occurred at various times in individuals of these two groups.

The proportion of females with progesterone concentrations $<1.5 \mathrm{ng} / \mathrm{ml}$ at Days $30-35$ was very similar whether or not PSPB was detected (8/21, Group 3; 4/10, Group 4). Correlative analysis 
Table 2. Correlation coefficients between progesterone and PSPB concentrations at the different days of pregnancy and at time of rectal palpation for animals (83) in Group 2

\begin{tabular}{|c|c|c|c|c|c|c|c|c|}
\hline \multirow[b]{2}{*}{$\begin{array}{l}\text { Stage of } \\
\text { pregnancy }\end{array}$} & \multicolumn{4}{|c|}{ Progesterone conc. } & \multicolumn{4}{|c|}{ PSPB conc. } \\
\hline & $\begin{array}{c}\text { Day } \\
24\end{array}$ & $\begin{array}{c}\text { Day } \\
26\end{array}$ & $\begin{array}{c}\text { Day } \\
30-35\end{array}$ & $\begin{array}{c}\text { Rectal } \\
\text { palpation }\end{array}$ & $\begin{array}{c}\text { Day } \\
24\end{array}$ & $\begin{array}{c}\text { Day } \\
26\end{array}$ & $\begin{array}{c}\text { Day } \\
30-35\end{array}$ & $\begin{array}{c}\text { Rectal } \\
\text { palpation }\end{array}$ \\
\hline $\begin{array}{l}\text { Progesterone } \\
24 \\
26 \\
30-35 \\
\text { Rectal } \\
\quad \text { palpation }\end{array}$ & $\begin{array}{l}1 \\
0.454^{* *} \\
0.236^{*} \\
\\
0.14\end{array}$ & $\begin{array}{l}1 \\
0.297^{* *} \\
0.153\end{array}$ & $\begin{array}{c}1 \\
-0.01\end{array}$ & 1 & & & & \\
\hline $\begin{array}{l}\text { PSPB } \\
24 \\
26 \\
30-35 \\
\text { Rectal } \\
\quad \text { palpation }\end{array}$ & $\begin{array}{c}-0 \cdot 114 \\
-0 \cdot 184 \\
-0 \cdot 138 \\
0 \cdot 101\end{array}$ & $\begin{array}{l}0 \cdot 155 \\
0 \cdot 101 \\
0 \cdot 08 \\
\\
0 \cdot 108\end{array}$ & $\begin{array}{l}0.08 \\
0.006 \\
0.072 \\
\\
0.08\end{array}$ & $\begin{array}{l}0.124 \\
0.110 \\
0.099 \\
\\
0.04\end{array}$ & $\begin{array}{l}1 \\
0.937^{* *} \\
0.717^{* *} \\
0.183\end{array}$ & $\begin{array}{l}1 \\
0.794^{* *} \\
0.211\end{array}$ & $0.257^{*}$ & 1 \\
\hline
\end{tabular}

${ }^{*} P<0 \cdot 05 ;{ }^{* *} P<0 \cdot 01$.

Table 3. Concentrations of PSPB during the first 70 days after AI in cows in Group 2 or Group 4 (late embryonic mortality)

\begin{tabular}{lcccc}
\hline & \multicolumn{4}{c}{ Time after AI } \\
\cline { 2 - 5 } Group & $\begin{array}{c}\text { Day } \\
24\end{array}$ & $\begin{array}{c}\text { Day } \\
26\end{array}$ & $\begin{array}{c}\text { Day } \\
30-35\end{array}$ & $\begin{array}{c}\text { At } \\
\text { rectal palpation }\end{array}$ \\
\hline 2 & $0.42 \pm 0.07(83)$ & $0.87 \pm 0.08(83)$ & $1.98 \pm 0.13(83)$ & $4.06 \pm 0.30(77)$ \\
4 & $0.27 \pm 0.07(10)$ & $0.53 \pm 0.10(10)$ & $1.28 \pm 0.34(10)$ & $0.2 \pm 0.15(6)$ \\
\hline
\end{tabular}

Values are mean \pm s.e.m. for the no. of cows given in parentheses.

for cows showed that the mean interval between time of AI and return to oestrus was not significantly longer in Group $4(48.5 \pm 11.5$ days, $N=5)$ than in Group $3(38.4 \pm 5.2$ days, $N=4)$; however, those intervals differed $(P<0.01)$ from those of Group $1(24.9 \pm 2$ days, $N=35)$.

Between 24 and 30-35 days after AI, pregnant females (Group 2) had higher $(P<0.025)$ PSPB concentrations than did those of Group 4 (Table 3). Figure 1 illustrates the differences $(P<0.005)$ in rate of increase of PSPB concentration in these two groups between 24 and 30-35 days after AI. Additionally, no interaction between status (pregnant or late embryonic mortality) and stage of pregnancy was found.

The large variation of PSPB concentrations at 30 days in Group 4 reflects the variation in the time of embryo death; only 2 cows had concentrations lower than the limit of detection of the assay. After 30 days, concentrations increased in pregnant cows (Group 2) and declined to undetectable levels in Group 4 females (Fig. 1). In Group 4 only 1 heifer had a detectable concentration of PSPB (i.e. $0.96 \mathrm{ng} / \mathrm{ml}$ ) at the time of rectal palpation.

\section{Relationship between progesterone and PSPB concentrations in females in Groups 2 and 4}

In pregnant animals (Group 2), correlation coefficients between progesterone and PSPB concentrations were not significantly different from zero (Table 2) at any stage of pregnancy. At Day 


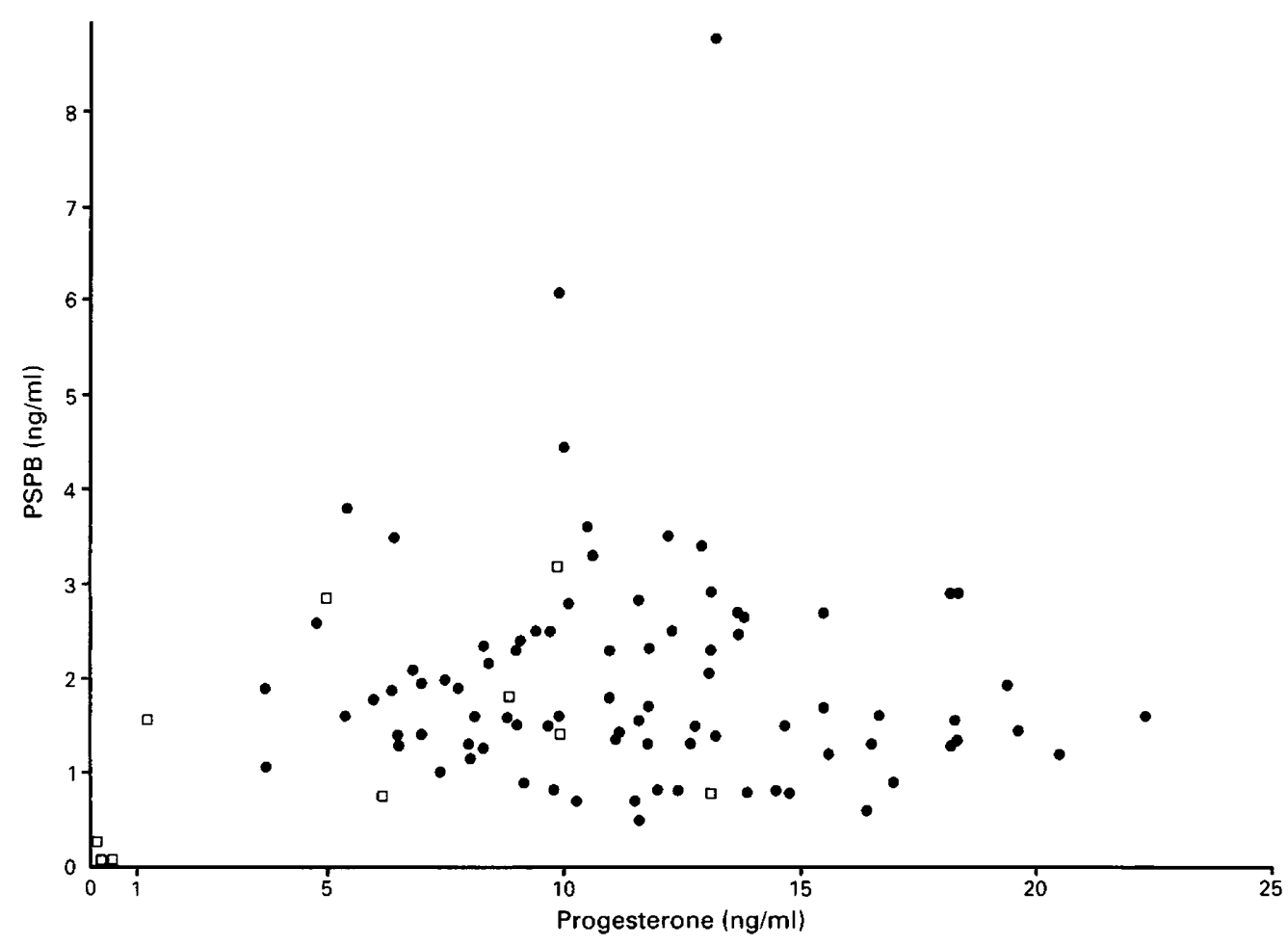

Fig. 2. Individual progesterone and PSPB concentrations in Group 1 cows ( $\bullet$, pregnant) and Group 4 cows ( $\square$, late embryonic mortality) at 30-35 days after AI.

30-35, there was no relationship between progesterone and PSPB concentrations in animals in Groups 2 and 4 (Fig. 2). Figure 2 further illustrates the fact that most of the females in Group 4 (6/ 10 ) at 30 days had progesterone and PSPB concentrations very similar to those of pregnant ones.

\section{Discussion}

In pregnant animals, mean progesterone concentrations at Day 24 and at subsequent stages of pregnancy were very similar to values reported by Eley et al. (1979), Bartol et al. (1981) and Knickerbocker et al. (1986). These levels were slightly higher than those observed at earlier stages (Days 18-21) by Glencross et al. (1973), Lukaszewska \& Hansel (1980), Glencross \& Pope (1981), Roche et al. (1985) and Lucy \& Stevenson (1986). This confirms that, after an initial rise during the first 3 weeks of pregnancy, progesterone concentrations remain stable throughout the first third of gestation (Donaldson et al., 1970; Heap et al., 1973). The fact that, in pregnant animals, no relationship seemed to exist between progesterone concentrations at the beginning of pregnancy and the time of rectal palpation, at 70 days, suggests that after Day 30 progesterone production may be regulated by factors other than those involved in the antiluteolytic mechanism. It is possible that luteotrophic factors such as those described by Hickey \& Hansel (1987) or found in allantoic fluid by Hickey et al. (1985) influence progesterone production by the CL later during pregnancy.

It is confirmed here, by analysis of progesterone concentration on Day 24 and by observed early return to oestrus, that about $60 \%$ of pregnancy failures result from non-fertilization or early embryonic death (Ayalon, 1978; Diskin \& Sreenan, 1980; Humblot, 1986) before the moment (Day 16) at which the antiluteolytic signal is present (Northey \& French, 1980; Humblot \& Dalla Porta, 
1984). In most of these early failures ( $>95 \%$ ), an elevation of PSPB concentrations was not detectable at or after 24 days. This reflects the lack of major development of trophoblastic tissue and suggests that a few cases of early embryonic death (without any prolongation of CL function) are associated with a very low PSPB production. Moreover, among cows with a delayed luteolysis, the females with detectable PSPB concentrations had, at Day 24, higher progesterone concentrations than did those with undetectable PSPB concentrations. This suggests that the production of the antiluteolytic signal and of PSPB could be related at the beginning of pregnancy. This is consistent with the fact that both PSPB (Reimers et al., 1985) and antiluteolytic protein(s) (Martal et al., 1984; Heyman et al., 1984) are released by trophoblastic cells.

The fact that no quantitative relationship between progesterone and PSPB concentrations exists in pregnant animals, whatever the stages of pregnancy, indicates that there is no effect of PSPB on progesterone production, or vice versa, under physiological conditions. At 24 days after AI, mean progesterone concentrations in animals expressing late embryonic death were lower than those from pregnant cows. Such a difference has been described in the first 18 days of pregnancy but in relation to early embryonic mortality or fertilization failure (Hansel, 1981). This confirms the report by Cavestany \& Foote (1985) from milk progesterone values that high progesterone concentrations in the first 24 days of gestation are associated with pregnancy maintenance. At subsequent stages after AI among those cows expressing late embryonic mortality, no difference in progesterone concentrations was found between females whether or not they had elevated PSPB concentrations. Moreover, at 30 days after AI, the proportion of cows which had completed luteolysis was very similar in these two groups and no difference was found in terms of return to oestrus. This shows that, despite higher progesterone concentrations on Day 24 in cows with PSPB production, luteolysis was not delayed further.

As in a previous work (Sasser et al., 1986) we observed a wide variation in the moment at which PSPB was first detected in pregnant animals. In this study it was only at 30 days after AI that all pregnant cows had elevated plasma PSPB concentrations. At this stage of pregnancy, there was a large range of PSPB concentrations. Almost all cows with detectable PSPB values in which late embryonic mortality was observed presented concentrations very similar to those found in cows which remained pregnant. Consequently, at 30 days it was impossible to differentiate those cows that were to remain pregnant from the few that did not by PSPB assay alone or even when combined with progesterone concentrations.

From 31 non-pregnant cows which had a delay in luteolysis only one third had detectable PSPB concentrations. This low rate of pregnancy failures associated with elevated PSPB concentrations explains the high accuracy of the RIA for PSPB when used as a pregnancy test (Sasser et al., 1986; Sasser \& Ruder, 1987; Humblot et al. 1988). Moreover, this shows that measurement of both progesterone and PSPB in peripheral plasma can be very useful to study the way in which various factors may chronologically affect embryonic mortality.

We thank the United Dairymen of Idaho for partial financial assistance; and D. Durand and J. Drach (CFEBR, Tournan en Brie 77220, France) for their help in organizing the experiment.

\section{References}

Ayalon, N. (1978) A review of embryonic mortality in cattle. J. Reprod. Fert. 54, 483-493.

Bartol, F.F., Thatcher, W.W., Bazer, F.W., Kimball, F.A., Chenault, J.R., Wilcox, L.J. \& Roberts, R.M. (1981) Effects of the estrous cycle and early pregnancy on bovine uterine, luteal and follicular response. Biol. Reprod. 25, 759-776.

Bartol, F.F., Roberts, R.M., Bazer, F.W., Lewis, G.S., Godkin, J.D. \& Thatcher, W.W. (1984) Characteriz- ation of proteins produced in vitro by periattachment bovine conceptuses. Biol. Reprod. 32, 681-694.

Betteridge, K.J., Eaglesome, M.D., Randall, G.C.B. \& Mitchell, D. (1980) Collection, description and transfer of embryos from cattle 10-16 days after oestrus. J. Reprod. Fert. 59, 205-216.

Butler, J.E., Hamilton, W.C., Sasser, R.G., Ruder, C.A., Hass, G.M. \& Williams, R.J. (1982) Detection and 
partial characterization of two bovine pregnancy specific proteins. Biol. Reprod. 26, 925-933.

Cavestany, D. \& Foote, R.H. (1985) The use of milk progesterone and electronic vaginal probes as aids in large dairy herd reproduction management. Cornell Vet. 75, 441-453.

Diskin, M.G. \& Sreenan, J.R. (1980) Fertilization and embryonic mortality rates in beef heifers after artificial insemination. J. Reprod. Fert. 59, 463-468.

Donaldson, L.E., Bassett, J.M. \& Thorburn, G.D. (1970) Peripheral plasma progesterone concentration of cows during puberty, oestrous cycles, pregnancy and lactation and the effects of undernutrition or exogenous oxytocin on progesterone concentration. $J$. Endocr. 48, 599-614.

Eley, R.M., Thatcher, W.W. \& Bazer, F.W. (1979) Hormonal and physical changes associated with bovine conceptus development $J$. Reprod. Fert. 55, 181-190.

Eley, R.M., Thatcher W.W., Bazer, F.W. \& Fields, M.J. (1983) Steroid metabolism by the bovine uterine endometrium and conceptus. Biol. Reprod.28, 804-816.

Gadsby, J.E., Heap, R.B. \& Burton, R.D. (1980) Oestrogen production by blastocyst and early embryonic tissue of various species. J. Reprod. Fert. 60, 409-417.

Glencross, R.G. \& Pope, G.S. (1981) Concentrations of oestradiol-17 $\beta$ and progesterone in the plasma of dairy heifers before and after cloprostenol-induced and natural luteolysis and during early pregnancy. Anim. Reprod. Sci. 4, 93-106.

Glencross, R.G., Munro, I.B., Senior, B.E. \& Pope, G.S. (1973) Concentrations of oestradiol-17 $\beta$, oestrone and progesterone in jugular venous plasma of cows during the oestrous cycle and in early pregnancy. Acta endocr., Copenh. 73, 374-384.

Godkin, J.D., Bazer, F.W., Sessions, F. \& Roberts, R.M. (1982) Purification and properties of a major low molecular weight protein released by the trophoblast of sheep blastocysts at Days 13-21. J. Reprod. Fert. 65, 141-150.

Godkin, J.D., Bazer, F.W. \& Roberts, R.M. (1984a) Ovine trophoblast protein 1 , an early secreted blastocyst protein, binds specifically to uterine endometrium and affects protein synthesis. Endocrinology 114, 120-130.

Godkin, J.D., Bazer, F.W., Thatcher, W.W. \& Roberts, R.M. (1984b) Proteins released by cultured Day 15 16 conceptuses prolong luteal maintenance when introduced into the lumen of cyclic ewes. $J$. Reprod. Fert. 71, 57-64.

Heap, R.B., G.M., Laing, J.A. \& Walters, D.E. (1973) Pregnancy diagnosis in cows; changes in milk progesterone concentration during the oestrous cycle and pregnancy measured by a rapid radioimmunoassay. J. agric. Sci., Camb. 81, 151-157.

Helmer, S.D., Hansen, P.J., Thatcher, W.W., Roberts, R.M. \& Bazer, F.W. (1985) Similarities between ovine and bovine conceptus secretory proteins (o CSP, b CSP) associated with luteal maintenance. $J$. Anim. Sci. 61, (Suppl. 1), 400-401, Abstr.

Hansel, W. (1981) Plasma hormone concentrations associated with early embryo mortality in heifers. $J$. Reprod. Fert., Suppl. 30, 231-239.

Heyman, Y., Camous, S., Fevre, J., Meziou, W. \& Martal, J. (1984) Maintenance of the corpus luteum after uterine transfer of trophoblastic vesicles to cyclic cows and ewes. J. Reprod. Fert. 70, 533-540.

Hickey, G.J. \& Hansel, W. (1987) In vitro synthesis of a low weight lipid soluble luteotrophic factor by conceptuses of cows at Day 13-18 of pregnancy. $J$. Reprod. Fert. 80, 569-576.

Hickey, G.J., Walton, J.S., Harper, H. \& Hansel, W. (1985) Partial purification of a luteotropic substance from allantoic fluids of 28-37 day bovine conceptuses. Biol Reprod. 32, (Suppl. 1), 64, Abstr.

Humblot, P. (1986) La mortalité embryonnaire chez les bovins. In Recherches récentes sur l'épidémiologie de la ferilité, pp. 213-242. Masson, Paris.

Humblot, P. \& Dalla Porta, M. (1984) Effect of conceptus removal and intrauterine administration of conceptus tissue on luteal function in the cow. Reprod. Nutr. Dévélop. 24, 529-541.

Humblot, P., Camous, S., Martal, J., Charlery, J., Jeanguyot, N., Thibier, M. \& Sasser, R.G. (1988) Diagnosis of pregnancy by radioimmunoassay of a pregnancy specific protein in the plasma of dairy cows. Theriogenology, in press.

Knickerbocker, J.J., Thatcher, W.W., Bazer, F.W., Drost, M., Baron, D.H., Fincher, K.B. \& Roberts, R.M. (1986) Proteins secreted by Day 16 to 18 bovine conceptuses extend corpus luteum function in cows. J. Reprod. Fert. 77, 381-391.

Lellouch, J. \& Lazar, P. (1974) Méthodes statistiques en Experimentation biologique. Flammarion, Paris.

Lewis, G.S., Thatcher, W.W., Bazer, F.W. \& Curls, J.S. (1982) Metabolism or arachidonic acid in vitro by bovine blastocysts and endometrium. Biol. Reprod. $27,431-439$.

Lukaszewska, J. \& Hansel, W. (1980) Corpus luteum maintenance during early pregnancy in the cow. $J$. Reprod. Fert. 59, 485-493.

Lucy, M.G. \& Stevenson, J.S. (1986) Gonadotropin releasing hormone at estrus: luteinizing hormone estradiol and progesterone during the periestrual and post insemination periods in dairy cattle. Biol. Reprod. 35, 300-311.

Martal, J., Lacroix, M., Loudes, C., Saunier, M. \& Wintenberger-Torres, S. (1979) Trophoblastin an antiluteolytic protein present in early pregnancy in sheep. J. Reprod. Fert. 56, 63-73.

Martal, J., Camous, S., F.J., Charlier, M. \& Heyman, Y. (1984) Origin of embryonic signals allowing the establishment of pregnancy corpus luteum in ruminants. Proc. 10th Int. Congr. Anim. Reprod. \& A.I., Urbana-Champaign, Vol. III, p. 509.

Northey, D.L. \& French, L.R. (1980) Effect of embryo removal and intrauterine infusion of embryonic homogenates on the lifespan of bovine corpus luteum. J. Anim. Sci. 50, 298-302.

Reimers, T.J., Sasser, R.G. \& Ruder, C.A. (1985) Production of pregnancy specific protein B (bPSPB) by bovine binucleate trophoblastic cells. Biol. Reprod. 32, (Suppl. 2), 65, Abstr.

Roche, J.F., Ireland, J.J., Boland, M.P. \& McGeady, T.M. (1985) Concentrations of luteinising hormone and progesterone in pregnant and non pregnant heifers. Vet. Rec. 116, 153-155.

Ruder, C.A. \& Sasser, R.G. (1986) Source of bovine pregnancy specific protein B (bPSPB) during the 
post-partum period and estimation of half life of bPSPB. J. Anim. Sci. 63, (Suppl.1), 335, Abstr.

Sasser, R.G. \& Ruder, C.A. (1987) Detection of early pregnancy in domestic ruminants. J. Reprod. Fert., Suppl. 34, 261-271.

Sasser, R.G., Ruder, C.A., Ivani, K.A., Butler, J.E. \& Hamilton, W.C. (1986) Detection of pregnancy by radioimmunoassay of a novel pregnancy specific protein in serum of cows and a profile of serum concentrations during gestation. Biol. Reprod. 35, 936-942.

Sauer, M.J. (1979) Hormone involvement in the establishment of pregnancy. J. Reprod. Fert. 56, 725-743.

Shemesh, M., Milaguir, F., Ayalon, N. \& Hansel, W. (1979) Steroidogenesis and prostaglandin synthesis by cultured bovine blastocysts. $J$. Reprod. Fert. 56, 181-185.
Snedecor, G.W. \& Cochran, W.G. (1956) Statistical Methods. Iowa State University Press, Ames.

Thibier, M., Castanier, M., Tea, N. \& Scholler, R. (1973). Concentrations plasmatiques de la $17 \alpha$ hydroxyprogesterone au cours du cycle de la vache. $C$. $r$. hebd. Séanc. Acad. Sci. Paris, D 276, 3049-3052.

Thibier, M. \& Saumande, J. (1975) Oestradiol-17ß progesterone and 17 $\alpha$-hydroxyprogesterone concentration in jugular venous plasma in cows prior to and during oestrus. J. Steroid Biochem. 6, 1433-1437.

Received 10 August 1987 